\author{
Magdenko S. \\ Assistant \\ Department of Industrial Economics \\ Odessa National Academy of Food Technologies \\ Kanatna str., 112, Odessa, Ukraine, 65039 \\ E-mail:maglana@meta.ua
}

\title{
MODERN STATE AND TRENDS OF STEADY DEVELOPMENT OF FOOD INDUSTRY ON THE EXAMPLE OF MEAT PROCESSING SECTOR
}

In the article the modern state and basic trends in development of meat processing industry are considered within the limits of food industry of Ukraine. The possible prospects of steady development of enterprises of meat processing industry are studied on the basis of introduction of achievements of STP and innovative development.

Keywords: tendency, innovation, enterprise, efficiency, sector, competition, development.

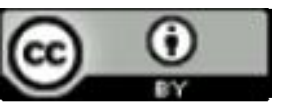

This work is licensed under a Creative Commons Attribution 4.0 International License http://creativecommons.org/licenses/by/4.0/
Statement of the problem and its connection with important scientific and practical tasks. Food industry is the constituent of agroindustrial complex of Ukraine. Therefore efficiency of its development depends on directions and tendencies of the progress of all AIC trends, beginning with development of agriculture that is the supplier of 75-80\% raw material for food industry, development of mechanical engineering for food industry, its quality and process of forming the infrastructure of AIC (transporting, storage).

Meat processing sector as subsector of food industry takes front positions on providing the population with food products providing the consumer with fresh meat, sausage products, smoked products, canned meat, ready-to-cook foods and subproducts. The market of meat and meat products is the major food market segment of country steady development, which has a strategic value. Meat processing sector is the base of the food complex of Ukraine and remains priority and strategic.

In the conditions of globalization and association in EU, competitive activity grows considerably both at the internal and external market for a consumer that needs providing of additional requirements such as: transition to the international standards of quality, innovative development of enterprises of a sector, ecofriendliness of products and complex processing of raw material and maintenance of resources.

The analysis of the latest publications on the problem. The analysis of the last research and publications proved that the issue of tendencies, prospects, patterns of development of food industry including meat processing sector was dealt with by many scientistseconomists, among whom are: Bohatyrov A.N., Borshchevskyi P. P., Deineko L. V., Drahan O.I., Zainchkovskyi P. M., Zaremba P.O., Krysanov D. F., Priadko V. V.,
Sabluk P.T, Sedikova I.O., Yankovoi V.O. and others. At the same time the issues of providing the steady development of food industry and its subindustries remain unsolved including meat the processing sector.

Forming of the aims of the research.The aim of the article consists of analysis of the modern state and characteristic tendencies in progress of food industry including the meat processing sector in the exposure of problems that substantially influence both the state and steady development of meat processing sector within the limits of the agroindustrial complex.

Giving an account of the main results and their substantiation. For providing of steady development of food industry from one side a number of conditions: is they are stability, economic stability, financecredit stability and equal terms required of availability of any entity to credit resources for introduction of modern technical-technological processes on the innovative basis. On the other hand, it is necessary to create stimulating conditions that will assist the increase of production volumes, upgrading of products including its ecological safety.

As an element in the structure of AIC, food industry may develop only in co-operation with other branches of AIC and first of all with agriculture that provides food industry with raw material. Therefore opportunities to increase the production volumes directly depend on possibility to get the necessary amount of raw material.

In table 1 interconnection between the volumes of the realized industrial products, food products and meat products is shown [1].

We will study what was happening with the production of meat in an agrarian sector in the last few years that is the basic raw material for meat processing enterprises, how the structure of its production changed. 
Table 1

Dynamics of volume of realization of products during $2011-2016 *$

\begin{tabular}{|l|c|c|c|c|c|c|}
\hline \multirow{2}{*}{ Indexes } & \multicolumn{7}{c|}{ Years } \\
\cline { 2 - 7 } & 2011 & 2012 & 2013 & 2014 & 2015 & 2016 \\
\hline Volume of the realized industrial products, bln UAH & 1331,9 & 1400,7 & 1354,1 & 1428,8 & 1776,6 & 1821,3 \\
\hline $\begin{array}{l}\text { Volume of production realization of food products, be- } \\
\text { verages, tobacco products, bln UAH }\end{array}$ & 222,4 & 254,5 & 261,8 & 302,4 & 398,0 & 411,4 \\
\hline In \% to the general volume of realization & 16,7 & 18,2 & 19,3 & 21,2 & 22,4 & 22,6 \\
\hline $\begin{array}{l}\text { Volume of production realization of food products, bln } \\
\text { UAH }\end{array}$ & 177,1 & 184,8 & 194,1 & 234,8 & 310,3 & - \\
\hline $\begin{array}{l}\text { In \% to the production volume of food products, beve- } \\
\text { rages, tobacco products }\end{array}$ & 79,6 & 72,6 & 74,2 & 77,6 & 77,9 & - \\
\hline $\begin{array}{l}\text { Volume of production realization of meat and meat } \\
\text { products, bln UAH }\end{array}$ & 27,4 & 31,3 & 32,8 & 38,4 & 51,9 & - \\
\hline In \% to the volume of food products production & 12,3 & 12,3 & 12,5 & 12,7 & 13,1 & - \\
\hline
\end{tabular}

* It is calculated by the author on the basis of growth rates of industrial production volume according to the data [1]

General volume of their actual production of is shown in table $2[2,3]$. meat by enterprises of agrarian sector during $2012-2016$

Table 2

Actual production of meat in Ukraine during 2012 - 2016*

\begin{tabular}{|c|c|c|c|c|c|c|c|c|c|c|}
\hline \multirow{2}{*}{ Types of meat } & \multicolumn{2}{|c|}{2012} & \multicolumn{2}{|c|}{2013} & \multicolumn{2}{|c|}{2014} & \multicolumn{2}{|c|}{2015} & \multicolumn{2}{|c|}{2016} \\
\hline & Thous.t & $\%$ & Thous.t & $\%$ & Thous.t & $\%$ & Thous.t & $\%$ & Thous.t & $\%$ \\
\hline Pork & 700,8 & 31,71 & 764,6 & 31,88 & 753,6 & 32,39 & 759,7 & 32,70 & 760,7 & 32,75 \\
\hline Cattle & 388,5 & 17,58 & 402,6 & 16,79 & 404,8 & 17,40 & 384 & 16,53 & 364,5 & 15,69 \\
\hline Poultry of all types & 1074,7 & 48,63 & 1190,8 & 49,66 & 1168,6 & 50,22 & 1143,7 & 49,23 & 1170,9 & 50,40 \\
\hline Other types & 46 & 2,08 & 40 & 1,67 & 0 & 0,00 & 35,6 & 1,53 & 26,9 & 1,16 \\
\hline Total & 2210 & 100,00 & 2398 & 100,00 & 2327 & 100,00 & 2323 & 100,00 & 2323 & 100,00 \\
\hline
\end{tabular}

* calculated by the author from data $[2,3]$

The data of table 2 testifies about different orientation tendencies of production of certain types of meat at general decline in its production including meat of cattle and pork, only the production of poultry has a tendency to increase both by absolute values and by the structure of production by years from $48,63 \%$ in 2012 to $50,40 \%$ in 2016.

We will study how production of meat volume changed in dynamics by the types during 2012-2016.

Table 3

Dynamics of actual production of meat during 2012-2016, \%*

\begin{tabular}{|l|c|c|c|c|c|}
\hline \multicolumn{1}{|c|}{ Types of meat } & 2012 & 2013 & 2014 & 2015 & 2016 \\
\hline Pork & 100,00 & 109,10 & 107,53 & 108,40 & 108,55 \\
\hline Cattle & 100,00 & 103,63 & 104,20 & 98,84 & 93,82 \\
\hline Poultry of all types & 100,00 & 110,80 & 108,74 & 106,42 & 108,95 \\
\hline Other types & 100,00 & 86,96 & 0,00 & 77,39 & 58,48 \\
\hline Total & 100,00 & 108,51 & 105,29 & 105,11 & 105,11 \\
\hline
\end{tabular}

*It is calculated by the author from data $[2,3]$

The calculations of the dynamics of meat production show that from 2015 there is a tendency to the decline of production of meat of cattle and other kinds, but insignificant increase of production of poultry and pork.

The coefficients of sufficiency of consumption of meat and meat products by the population of Ukraine hesitate within the limits of $0,64-0,7$ by years at the rational norm of consumption of meat $80 \mathrm{~kg} /$ per person $[4$, p. 62]. That is why it is possible to say that suggestion of production of meat dissatisfies the rational norms of consumption. 
However capacity of meat processing enterprises are used at level from 35 to 60 percent. Possibilities of the capacity allow to increase the production volume, but there is a number of factors that do it impossible at this stage of functioning of meat processing sector. Among these factors it is possible to distinguish:

- problems of providing with national raw material while a big amount of imported raw material depends on the currency exchange rate and may result in the threat of industry dependence from import, decrease the competitiveness of products on price parameters;

- $\quad$ sharp decline of purchasing ability of national currency;

- low purchasing ability of population that limits development of internal consumer market of meat;

- $\quad$ loss of considerable internal market of sale in connection with ATO on the East and with the loss of Crimea. A foreign market also diminished due to abandonment of the Russian market.

European market for national producers is not open enough yet because of a number of limiting factors : quotas of supply on the separate types of products, not meeting the requirements of the European standards of national technologies, level of ecological security of products [5].

The decision of issues on expansion of production and increase of efficiency of functioning of meat processing sector needs complex approach.

For solution of the problem in relation to providing of meat processing enterprises with national raw material it is necessary to increase growing of head of cattle and pigs. For this purpose it is necessary to stimulate farmer and agricultural entities, households with possibility of receiving of favourable credits, tax deductions, state support.

The order of Cabinet of Ministers of Ukraine from 30.12.2015 № 1437-r. affirmed «Conception of the State target program of the agrarian sector development of economy for a period up to 2020». The essence of the Program is that the value of AIC is revealed as one of the important constituents of the budget, almost 12 percent [6]. Also the problems in development of AIC branches have been stated and the directions of realization of their further development including the development of livestock in agriculture and expansion of markets of production of food industry distribution have been pointed out. However, the offered Program does not solve existing problems in complex because the development of the agrarian sector, including livestock, needs solving the social problem of village simultaneously.

In the Program the decision of a number of problems is determined by means of the State [6]. At the same time the Budget of Ukraine for 2017 only 170,0 million $\mathrm{UAH}$ is laid on development of livestock [7].

The main deterrent is a limited solvency of national consumers that at first diminished gradually and through devaluation of hryvnya at the end of 2014 sharply fell down by three times. The next reason of reduction of population solvency was an increase of tariffs on all energy resources and utility bills. All this hit hard on the whole food industry. The consumer basket of population diminished considerably, priorities at the choice of purchase of food products changed. Practically the third part of population is not able now to buy qualitative food including meat products: demand on sausages of the top grade went down considerably, mainly it people began to buy the boiled sausage, sausages, subproducts.

To substantially promoting the purchasing ability of population is possible by the increase of salaries and pensions as well as price-cutting on products at the expense of to reduction of constituents of the cast price at the expense of to introduction of the newest technological, technical and organizational innovations. But the issue of introduction of innovative decisions needs considerable amount of money that the most enterprises do not have. Availability of the credits is also limited by the high rates on credits, to get investment long-term credits is practically impossible. So there is a need in strategy of complex decision of this problem.

At the agrarian market the basic producers of meat in Ukraine are MBP, Complex "Agromars", "AgroOven" that in 2015 occupy 54,5\% of market. Among the meat processing enterprises the market of sausage products of Ukraine is diversified enough and on one player it will be no more than $7 \%$ of market. Among the largest producers it is worth to mark LTD "Meat-packing plant "Anniversary", PLC "Meat-packing plant "Yatran", LTD "Globynskyi meat-packing plant" and others [8].

One of the effective directions in increase of efficiency of functioning of food industry including enterprises of meat processing sector, the development of integration connections and construction of integral associations is considered. As N. Skopenko marks, more considerable competitive advantages on their basis (in particular those that minimize dependence on suppliers and price-waves on raw material), those enterprises-producers of food products will have that will be included in the integration systems (cooperative stores, holdings, business concerns etc.) [9].

However, as experience of the countries of Eastern Europe shows the consequences of introduction of such integration systems can be estimated only in a longterm period [10].

Conclusions and prospects of the further investigations. Scientific research of the modern state of meat processing sector of Ukraine and providing its steady development lead to the following conclusions:

- strategy of development of enterprises of the meat processing sector must be based on taking into account the purchasing ability of population;

- for the increase of production of meat and meat products volumes it is necessary to apply various stimulation of export and limitation of import, expansion of state control of market relations in the field of AIC;

- providing of the steady development and functioning of meat processing enterprises is possible only on principles of optimization of economic relations between the producers of raw material and prepared meat products.

- for the increase of efficiency of production in 
meat processing sector, foremost, it is necessary to create or extend the own source of raw materials that has first and to make cheaper products of higher quality and cheaper;

- meat processing enterprises and producers of meat must make mutually beneficial links by means of different forms of the integration systems. A conquest of new markets of sale due to creation of own trade networks by vertical integration that is advisable to build by means of holdings or corporations formation, is very appropriate.

\title{
References
}

1. Ofitsiinyi sait Derzhavnoho komitetu statystyky. Retrieved March 11, 2017, from http://www.ukrstat.gov.ua

2. Ofitsiinyi sait Ukrainskoho klubu ahrarnoho biznesu. Retrieved March 11, 2017, from http://ucab.ua/ua/doing_agribusiness/agrarni_rinki/myaso

3. Informatsiina systema, v ramkakh proektu «Dialoh derzhavy ta biznesu v m'iasnomu sektori Ukrainy» Avtomatyzovanyi balans popytu ta propozytsii m'iasa Ukrainy. Retrieved March 11, 2017, from http://meatbalance.org.ua/

4. Oshchepkov, O. P., \& Mahdenko, S. O. (2016). Otsinka dynamiky rozvytku pidpryiemstv m'iasopererobnoi haluzi Ukrainy . Statystychna otsinka sotsialno-ekonomichnoho rozvytku: XVI vseukr. nauk.-prakt. konf., 26 travnia 2016 r., 61-64.

5. Brychko, A. M.. Vyrobnytstvo ta zbut m'iasa (ialovychyny, svynyny, m'iasa ptytsi) na vitchyznianomu ta svitovomu rynkakh . Retrieved May 11, 2017, from http://www.economy.nayka.com.ua/?op=1\&z=5421

6. Kontseptsiia Derzhavnoi tsilovoi prohramy rozvytku ahrarnoho sektoru ekonomiky na period do 2020 roku. Retrieved May 11, 2017, from http://www.kmu.gov.ua/control/uk/cardnpd?docid=248907971

7. Zakon Ukrainy «Pro derzhavnyi biudzhet Ukrainy na 2017 rik»: za stanom na 23 bereznia 2017 r. Retrieved May 11, 2017, from http://zakon3.rada.gov.ua/laws/show/1801-19

8. Top-10 proyzvodytelei miasa v Ukrayne. Retrieved March 11, 2017, from http://latifundist.com/rating/top10-proizvoditelej-myasa-v-ukraine-2015

9. Skopenko, N. S. (2011). Suchasnyi stan i perspektyvy rozvytku kharchovoi promyslovosti Ukrainy na osnovi formuvannia intehrovanykh struktur . Aktualni problemy ekonomiky, 4(118), 101-110.

10. Olefir, V. (2014). Rozvytok ahroprodovolchykh sektoriv Bolharii, Polshchi ta Rumunii v umovakh pohlyblennia yevrointehratsii . Ekonomist, 12, 65-68.

\author{
Магденко С.A. \\ старший преподаватель \\ кафедра экономики промышленности \\ Одесская национальная академия пищевых технологий \\ ул. Канатная, 112, м. Одеса, Украина, 65039 \\ E-mail: maglana1@meta.ua
}

\section{СОВРЕМЕННОЕ СОСТОЯНИЕ И ТЕНДЕНЦИИ УСТОЙЧИВОГО РАЗВИТИЯ ПИЩЕВОЙ ПРОМЫШЛЕННОСТИ НА ПРИМЕРЕ МЯСОПЕРЕРАБАТЫВАЮЩЕЙ ОТРАСЛИ}

В статье рассмотрено современное состояние и основные тенденции развития мясоперерабатывающей отрасли как составляющей пищевой промышленности Украины. Исследованы возможные перспективы устойчивого развития предприятий мясоперерабатывающей отрасли на основе внедрения достижений НТП и инновационного развития.

Эффрективность развития пищевой промышленности зависит от направлений и тенденций развития всего АПК, начиная с развития сельского хозяйства, которое является основным поставщиком сырья для пищевой промышленности, развития машиностроения для пищевой промышленности, его качества, и непосредственно процесса фрормирования инфраструктуры АПК.

Рынок мяса и мясопродуктов является важнейшим сегментом продовольственного рынка страны, устойчивое развитие которого имеет стратегическое значение. Мясоперерабатывающая от- 
расль является базисом продовольственного комплекса Украины и остается приоритетной и стратегической.

В условиях глобализации и ассоциации в ЕС значительно возрастает конкурентная борьба как на внутреннем, так и на внешнем рынке за потребителя, что требует обеспечения дополнительных требований, таких как: переход на международные стандарты качества, инновационное развитие предприятий отрасли, экологичность продукции и комплексной переработки сырья и ресурсосбережения.

Для обеспечения устойчивого развития пищевой промышленности, с одной стороны, необходим ряд условий: это - политическая стабильность, экономическая стабильность, фринансовокредитная стабильность и равные условия доступности любым субъектам хозяйствования к кредитным ресурсам для внедрения современных технико-технологических процессов на инновационной основе. С другой стороны, необходимо создавать стимулирующие условия, способствующие увеличению объемов производства, повышению качества продукции, в том числе ее экологической безопасности.

Ключевые слова: тенденция, инновация, предприятие, эфффективность, отрасль, конкуренция, развитие.

\author{
Магденко С.О. \\ старший викладач \\ кафедра економіки промисловості \\ Одеська національна академія харчових технологій \\ вул. Канатна, 112, м. Одеса, Україна, 65039 \\ e-mail: maglana1@meta.ua
}

\title{
СУЧАСНИЙ СТАН ТА ТЕНДЕНЦІЇ СТІЙКОГО РОЗВИТКУ ХАРЧОВОЇ ПРОМИСЛОВОСТІ НА ПРИКЛАДІ М'ЯСОПЕРЕРОБНОЇ ГАЛУЗІ
}

У статті розглянуто сучасний стан та основні тенденції розвитку м'ясопереробної галузі як складової харчової промисловості України. Досліджено можливі перспективи сталого розвитку підприємств м'ясопереробної галузі на основі впровадження досягнень НТП та інноваційного розвитку.

Ефективність розвитку харчової промисловості залежить від напрямків і тенденцій розвитку всього АПК, починаючи з розвитку сільського господарства, яке є основним постачальником сировини для харчової промисловості, розвитку машинобудування для харчової промисловості, його якості, i безпосередньо процесу формування інфраструктури АПК.

Ринок м'яса та м'ясопродуктів є найважливішим сегментом продовольчого ринку країни, сталий розвиток якого має стратегічне значення. М'ясопереробна галузь є базисом продовольчого комплексу України і залишається пріоритетною і стратегічної.

В умовах глобалізації та асоціації в ЄС значно зростає конкурентна боротьба як на внутрішньому, так і на зовнішньому ринку за споживача, що вимагає забезпечення додаткових вимог, таких як: перехід на міжнародні стандарти якості, інноваційний розвиток підприємств галузі, екологічність продукції і комплексної переробки сировини і ресурсозбереження.

Для забезпечення сталого розвитку харчової промисловості, з одного боку, необхідний ряд умов: це - політична стабільність, економічна стабільність, фрінансово-кредитна стабільність та рівні умови доступності будь-яким суб'єктам господарювання до кредитних ресурсів для впровадження сучасних техніко-технологічних процесів на інноваційній основі. 3 іншого боку, необхідно створювати стимулюючі умови, що сприяють збільшенню обсягів виробництва, підвищенню якості продукції, в тому числі її екологічної безпеки.

Ключові слова: тенденція, інновація, підприємство, ефективність, галузь, конкуренція, розвиток.

\section{Література}

1. Офіційний сайт Державного комітету статистики [Електронний ресурс]. - Режим доступу: http://www.ukrstat.gov.ua.

2. Офіційний сайт Українського клубу аграрного бізнесу [Електронний ресурс]. - Режим доступу: http://ucab.ua/ua/doing_agribusiness/agrarni_rinki/myaso 
3. Інформаційна система, в рамках проекту «Діалог держави та бізнесу в м’ясному секторі України» Автоматизований баланс попиту та пропозиції м’яса України [Електронний ресурс]. - Режим доступу: http://meatbalance.org.ua/.

4. Ощепков О.П. Оцінка динаміки розвитку підприємств м’ясопереробної галузі України / О.П. Ощепков, С.О. Магденко // Статистична оцінка соціально-економічного розвитку: XVI всеукр. наук.-практ. конф., 26 травня 2016 р. : зб. текстів доповідей. - Хмельницький, 2016. - С. 61 -64

5. Бричко А.М. Виробництво та збут м'яса (яловичини, свинини, м'яса птиці) на вітчизняному та світовому ринках [Електронний ресурс] / А.М. Бричко. - Режим доступу: http://www.economy.nayka.com.ua/?op=1\&z=5421

6. Концепція Державної цільової програми розвитку аграрного сектору економіки на період до 2020 року [Електронний ресурс]. - Режим доступу: http://www.kmu.gov.ua/control/uk/cardnpd?docid=248907971

7. Закон України «Про державний бюджет України на 2017 рік»: за станом на 23 березня 2017 р. [Електронний ресурс]. - Режим доступу: http://zakon3.rada.gov.ua/laws/show/1801-19

8. Топ-10 производителей мяса в Украине [Електронний ресурс]. - Режим доступу: http://latifundist.com/rating/top-10-proizvoditelej-myasa-v-ukraine-2015

9. Скопенко Н. С. Сучасний стан і перспективи розвитку харчової промисловості України на основі формування інтегрованих структур / Н. С. Скопенко // Актуальні проблеми економіки. - 2011. - №4 (118). - С. $103-110$

10. Олефір В. Розвиток агропродовольчих секторів Болгарії, Польщі та Румунії в умовах поглиблення євроінтеграції / В. Олефір // Економіст. - 2014. - № 12. - С. 65-68.

Стаття надійшла 04.04.2017 Стаття прийнята до друку 18.04.2017 Доступно в мережі Internet 30.06.2017 